\title{
Relationship of COVID-19 pathogenesis for periodontal medicine research. Part I: Pathogenesis of COVID-19
}

\author{
Relação da patogênese de COVID-19 para pesquisa de medicina periodontal. Parte I: Patogênese \\ da COVID-19
}

Relación de la patogénesis de COVID-19 para la investigación en medicina periodontal. Parte I: Patogénesis de COVID-19

Received: 03/09/2021 | Reviewed: 03/16/2021 | Accept: 04/13/2021 | Published: 04/25/2021

Davi da Silva Barbirato

ORCID: https://orcid.org/0000-0003-0527-6092 Federal University of Rio de Janeiro, Brazil

E-mail: davibarbirato@gmail.com

Mariana Fampa Fogacci

ORCID: https://orcid.org/0000-0003-3765-2152 Federal University of Pernambuco, Brazil E-mail: mari.fogacci@gmail.com

Pamella Oliveira de Azevedo

ORCID: https://orcid.org/0000-0001-9620-3256 Federal University of Rio de Janeiro, Brazil E-mail:pamellasetti@hotmail.com

Carmelo Sansone

ORCID: https://orcid.org/0000-0002-0293-5147 Federal University of Rio de Janeiro, Brazil E-mail: drcarmelosansone@gmail.com

João Régis Ivar Carneiro

ORCID: https://orcid.org/ 0000-0002-2085-8130 Federal University of Rio de Janeiro, Brazil E-mail: endoregis.carneiro@gmail.com

Maria Cynésia Medeiros de Barros

ORCID: https://orcid.org/0000-0002-2284-3581 Federal University of Rio de Janeiro, Brazil E-mail: cynesiaster@gmail.com

\begin{abstract}
Cell invasion mediated by angiotensin-converting enzyme 2 (ACE2) ectoenzyme and cellular proteases, such as trypsinlike proteases, cathepsins, transmembrane serine protease 2 and furin, target different tissues and organs as lung, gut, colon, ileum, kidney, gallbladder, heart muscle, epididymis, breast, ovary, stomach, bile duct, liver, oral cavity, lung, thyroid, esophagus, bladder, breast, uterus, prostate, pancreas, cerebellum, as well as calyx secreting cells in the nasal and sinus tissue. Loss of homeostasis of the renin-angiotensin system deregulates different axes compromising metabolic, cardiorespiratory, renal and hepatic control. SARS-CoV-2 infected cell undergoes pyroptosis and releases molecular patterns associated with damage: pro-inflammatory interleukin (IL) -1 $\beta$, IL-6, IL-8, IL-10, IL-17, induced protein-10, interferon gamma, interferon gamma-induced protein-10, granulocyte colony-stimulating factor, granulocyte-macrophage colony-stimulating factor, macrophage inflammatory protein $1 \alpha$ and $1 \beta$, monocyte chemotherapy activating protein 1 , inflammatory macrophage protein $1 \alpha$, tumor necrosis- $\alpha$, and mediators of immunemediated inflammatory diseases. Cytokine storm and non-neutralizing antibodies produced by B cells circulate, cause/exacerbate damage to various organs. During viral replication and low oxygen saturation, loss of HIF-mediated cell homeostasis can lead to cell death/lysis and tissue damage, related to the hyperinflammatory response. The SARSCoV-2-ACE2 can increase permeability, inflammation and microbial transmission by bacteremia or endotoxemia, in addition to dysbiosis. Thrombotic potential and the immunoinflammatory imbalance compromise function or lead to injuries and multiple organ failure. Infection by SARS-CoV-2 has the potential to modify the natural history of diseases, the relationships or interactions between the different systems and pathologies and the effects of their treatments, as in periodontal medicine approach.
\end{abstract}

Keywords: Coronavirus infections; Pathogenesis; Periodontics. 


\begin{abstract}
Resumo
A invasão celular mediada pela enzima conversora de angiotensina 2 (ACE2) ectoenzima e proteases celulares, tem como alvo diferentes tecidos e órgãos. A perda da homeostase do sistema renina-angiotensina desorganiza diferentes eixos, comprometendo o controle metabólico, cardiorrespiratório, renal e hepático. A célula infectada com SARS-CoV2 sofre piroptose e libera padrões moleculares associados a danos: interleucina pró-inflamatória (IL) -1 $\beta$, IL-6, IL-8, IL-10, IL-17, induzida por proteína-10, interferon gama, proteína induzida por interferon gama-10, fator estimulador de colônia de granulócitos, fator estimulador de colônia de granulócitos-macrófagos, proteína inflamatória de macrófagos $1 \alpha$ e $1 \beta$, proteína de ativação de quimioterapia de monócitos 1 , células inflamatórias de proteína de macrófagos 1 , necrose tumoral- $\alpha$ e mediadores de doenças inflamatórias mediadas. A tempestade de citocinas e os anticorpos não neutralizantes produzidos pelas células B circulam, exacerbando os danos a vários órgãos. Durante a replicação viral e a baixa saturação de oxigênio, a perda da homeostase celular mediada pelo HIF pode levar à morte/lise celular e danos aos tecidos, relacionados à resposta hiperinflamatória. O SARS-CoV-2-ACE2 pode aumentar a permeabilidade, inflamação e transmissão microbiana por bacteremia ou endotoxemia, além da disbiose. O potencial trombótico e o desequilíbrio imunoinflamatório comprometem a função ou levam a lesões e falência de múltiplos órgãos. A infecção por SARS-CoV-2 tem o potencial de modificar a história natural das doenças, as relações ou interações entre diferentes sistemas e patologias e os efeitos de seus tratamentos, como na abordagem da medicina periodontal.
\end{abstract}

Palavras-chave: Infecção por Coronavírus; Patogênese; Periodontia.

\title{
Resumen
}

La invasión celular mediada por la ectoenzima de la enzima convertidora de angiotensina 2 (ACE2) y las proteasas celulares, se dirige a diferentes tejidos y órganos. La pérdida de homeostasis del sistema renina-angiotensina desregula diferentes ejes, comprometiendo el control metabólico, cardiorrespiratorio, renal y hepático. La célula infectada con SARS-CoV-2 sufre piroptosis y libera patrones moleculares asociados con el daño: interleucina proinflamatoria (IL) $1 \beta$, IL-6, IL-8, IL-10, IL-17, proteína inducida-10, interferón gamma, proteína 10 inducida por interferón gamma, factor estimulante de colonias de granulocitos, factor estimulante de colonias de granulocitos-macrófagos, proteína inflamatoria de macrófagos $1 \alpha$ y $1 \beta$, proteína activante de quimioterapia de monocitos 1 , proteína de macrófagos inflamatorios $1 \alpha$, necrosis tumoral $\alpha$ y mediadores de enfermedades inflamatorias mediadas por el sistema inmunitario. La tormenta de citocinas y los anticuerpos no neutralizantes producidos por las células B circulantes agravan el daño a varios órganos. Durante la replicación viral y la baja saturación de oxígeno, la pérdida de homeostasis celular mediada por HIF puede provocar muerte/lisis celular y daño tisular, relacionado con la respuesta hiperinflamatoria. El SARSCoV-2-ACE2 puede aumentar la permeabilidad, la inflamación y la transmisión microbiana debido a bacteriemia o endotoxemia, además de disbiosis. El potencial trombótico y el desequilibrio inmunoinflamatorio comprometen la función o conducen a lesiones e insuficiencia multiorgánica. La infección por SARS-CoV-2 tiene el potencial de modificar la historia natural de las enfermedades, las relaciones o interacciones entre diferentes sistemas y patologías y los efectos de sus tratamientos, como en el enfoque de la medicina periodontal.

Palabras clave: Infecciones por Coronavirus; Pathogenesis; Periodoncia.

\section{Introduction}

SARS-CoV-2 infection appears to directly affect tissues and organs by exposure and presence of the angiotensinconverting enzyme 2 (ACE2) ectoenzyme and cellular proteases (Bertram et al., 2011, Glowacka et al., 2011, Raj et al., 2013, Wang et al., 2013, Gheblawi et al., 2020, Gralinski \& Menachery, 2020, Hoffmann et al., 2020, Wan, Shang, Graham, Baric \& $\mathrm{Li}, 2020$, Zhou et al., 2020). The lungs are the most affected organs and the clinical evolution of severe forms of COVID-19 leads to abnormalities in the blood hematological and biochemical index, and systemic conditions/diseases on kidney, liver and coagulation biomarkers (Tay, Poh, Rénia, MacAry \& Ng, 2020, Pedersen \& Ho, 2020, Schett, Sticherling \& Neurath, 2020, Zhang et al., 2020). The pathogenesis of COVID-19 and its systemic impacts are associated with intense pro-inflammatory events and loss of homeostasis, associated with a hyperinflammatory state, secondary bacterial infections, bacteremia, endotoxemia, loss of function and multiple organ failure (Cao \& Li, 2020, Chen et al., 2020, Hadjadj et al., 2020, Henry, de Oliveira, Benoit, Plebani \& Lippi, 2020, Huang et al., 2020, Mehta, McAuley, Brown, Sanchez, Tattersall \& Manson, 2020, Merad \& Martin, 2020, Qin et al., 2020, Wang, Jiang, Chen \& Montaner, 2020, Wu et al., 2020, Ye, Wang \& Mao, 2020, Zhou et al., 2020, GarcíaSastre, 2017, Schulert \& Grom, 2015, Mayer-Barber et al., 2014). The systemic impacts of the COVID-19 have the potential to influence the relationships and interactions between periodontal diseases and systemic conditions/diseases, previously reported in the literature. In addition, the periodontal medicine research, the natural history of periodontal disease and the response to 
periodontal therapy during and after the COVID-19 pandemic may be affected by the disease. Therefore, the aim of this study was to review the literature and propose a conceptual hypothesis on the subject, based on the interception between the pathogenesis of COVID-19 and its main systemic repercussions, and periodontal medicine.

\section{Methodology}

Theoretical essay based on studies on the pathogenesis of COVID-19, potentially related to systemic interactions of periodontal diseases. Searches were performed in the MEDLINE|PubMed, Scopus, Embase, Web of Science, Cochrane Library, and BIREME|bvs databases for articles published up to 2020 December 20, using MeSH terms, Emtree terms and DeCS/MeSH terms related to 'COVID-19', 'SARS-CoV-2', and 'pathogenesis', combined by the Boolean operators "OR" and "AND". The studies, mostly experimental and review, published in the main journals, were qualitatively summarized. The comparison of these findings with the main systemic interactions of periodontal diseases previously described resulted in conceptual hypotheses based on the literature about the potential impacts of the COVID-19 pandemic on the scientific investigation of these interactions.

\section{Results and Discussion}

\section{New coronavirus SARS-CoV-2 and host cell infection}

The first cases of COVID-19 (coronavirus disease 2019) were reported to the World Health Organization (WHO) on December 31, 2019, where 27 individuals suffered pneumonia with no known cause and all were related to a wholesale market for wet animals in the city of Wuhan, China. All available evidence for COVID-19 suggests that SARS-CoV-2 has a zoonotic source. The clinical signs and symptoms and the genetic similarity of the pathogen to the SARS-CoV virus resulted in the taxonomic characterization of a new coronavirus identified as SARS-CoV-2 (severe acute respiratory syndrome coronavirus 2) (Peiris, Guan \& Yuen, 2004, Cui, Li \& Shi, 2019, Committee on Taxonomy of Viruses, 2020, Lai, Shih, Ko, Tang \& Hsueh, 2020, World Health Organization, 2020a). In January 2020, the outbreak of COVID-19 was declared by WHO as a Public Health Emergency of International Importance, and on March 11 the pandemic of COVID-19 in the world was declared (World Health Organization, 2020b).

At least six other coronaviruses have been known to cause disease in humans, including viruses 229E, OC43, NL63 and HKU1; SARS-CoV and MERS-CoV are of zoonotic origin and can be fatal. SARS-CoV-2 (coronavirus genera $\beta$ ) is the seventh member of the family of coronaviruses that infect humans, (Fehr \& Perlman, 2015, Rabi, Al Zoubi, Kasasbeh, Salameh \& AlNasser, 2020, Tay, Poh, Rénia, MacAry \& Ng, 2020) related to systemic complications in different tissues and organs, hyperinflammatory reactions (cytokine storm that resembles secondary haemophagocytic lymphohistiocytosis), bacterial superinfections, sepsis and multiple organ failure. In severe cases of COVID-19, respiratory infections are associated with pneumonia and acute respiratory distress syndrome (ARDS) (Tay, Poh, Rénia, MacAry \& Ng, 2020, Pedersen \& Ho, 2020, Schett, Sticherling \& Neurath, 2020, Zhang et al., 2020). The severity and risk of death from COVID-19 may vary between individuals of same populations and are associated with risk factors, comorbidities and systemic abnormalities generally correlated/investigated in periodontal medicine research (Zhang, Penninger, Li, Zhong \& Slutsky, 2020, Zhu et al., 2019, van Boheemen et al., 2012)

Specific genes in the regions downstream of ORF1 encode proteins for viral replication, formation of nucleocapsids and spikes in coronaviruses (van Boheemen et al., 2012). Glycoprotein spikes are responsible for binding and entering the virus into host cells through binding to the ACE2 ectoenzyme and membrane fusion and conformational changes dependent on cellular proteases, which include trypsin-like proteases of the human airways (HAT), cathepsins and serine transmembrane protease 2 (TMPRSS2) (Bertram et al., 2011, Glowacka et al., 2011, Raj et al., 2013, Wang et al., 2013, Gheblawi et al., 2020, Gralinski \& Menachery, 2020, Hoffmann et al., 2020, Wan, Shang, Graham, Baric \& Li, 2020, Zhou et al., 2020). The receptor-binding 
domain (RBD) is loosely linked between viruses, so the virus's infectivity is highly efficient (Raj et al., 2013, Perlman \& Netland, 2009). The RBD region maintains the van der Waals forces and the 394 glutamine residue is recognized by the critical lysine 31 residue in the human ACE2 receptor (Wan, Shang, Graham, Baric \& Li, 2020).

Structural proteins are encoded by the structural genes spike $(\mathrm{S})$, envelope $(\mathrm{E})$, membrane $(\mathrm{M})$ and nucleocapsid $(\mathrm{N})$ (Chen, Liu \& Guo, 2020, Hui et al., 2020, Li et al., 2020, Lu et al., 2020, Wu et al., 2020). SARS-CoV-2 differs from SARS$\mathrm{CoV}$ in the absence of protein $8 \mathrm{a}$ and the number of amino acids in protein $8 \mathrm{~b}$ and $3 \mathrm{c}$ varies (Wu et al., 2020). Spike is a transmembrane trimetric glycoprotein protruding from the viral surface. It is related to the diversity of coronaviruses and host tropism. SARS-CoV-2 Spike glycoprotein was modified by homologous recombination as a mixture of bat SARS-CoV and an unknown Beta-CoV; ( $\mathrm{Li}$ et al., 2020) the N501T mutation in the SARS-CoV-2 Spike may have significantly increased its binding affinity for ACE2 (Wan, Shang, Graham, Baric \& Li, 2020) SARS-CoV-2 also expresses other polyproteins, nucleoproteins and membrane proteins, such as RNA polymerase, protease type 3-chymotrypsin, protease type papain, helicase, glycoprotein and accessory proteins (Wu et al., 2020, Zhou et al., 2020).

\section{Viral replication}

The life cycle of SARS-CoV-2 in host cells begins when the cleavage at the $S_{1} / S_{2}$ cleavage site of the Spike protein for binding to the ectoenzyme ACE2 (step 1, attachment - stabilization of the membrane-anchored $S_{2}$ subunit), followed by changes in conformation through protease cleavage for activation at the $\mathrm{S}_{2}{ }_{2}$ of the $\mathrm{S}_{2}$ subunit, resulting in fusion of the viral envelope with the host cell membrane and endocytosis (step 2, penetration via endosomal). Among coronaviruses, only SARS-CoV-2 presents a furin cleavage site ("RPPA" sequence) at the $S_{1} / S_{2}$ site. Although the $S_{1} / S_{2}$ site was also subjected to cleavage by TMPRSS2 and cathepsin B and L, the ubiquitous expression of furin likely makes this virus very pathogenic (Gheblawi et al., 2020, Hoffmann et al., 2020, Zhou et al., 2020, Caly, Druce, Catton, Jans \& Wagstaff, 2020, Moore, 2001). The virus's positive single-stranded RNA $\left(\mathrm{RNA}^{+}\right)$is released into the host cell and its genome is translated into viral polyproteins replicase ppla and $1 \mathrm{ab}$, cleaved into small products by viral proteinases (step 3, biosynthesis). The viral replication of SARS-CoV-2 depends on the cytoplasmic mechanism of the infected cell and occurs through series of subgenomic mRNA production by discontinuous transcription. Viral replication of SARS-CoV-2 can occur in the cytoplasm of the host cell, with the viral RNA ${ }^{+}$acting as mRNA. After a polymerase action, the mRNAs are translated into relevant viral proteins that are assembled into virions with RNA from the genome in the endoplasmic reticulum (ER), intermediate compartment ER-Golgi and Golgi complex (step 4, maturation). The virus is released out of the cell via the membrane transport system (step 5, release) (Luo, Chen, Chen, Chen, Shen \& Jiang, 2005, Frieman, Yount, Heise, Kopecky-Bromberg, Palese \& Baric, 2007, Shereen, Khan, Kazmi, Bashir \& Siddique, 2020, Yuki, Fujiogi \& Koutsogiannaki, 2020).

SARS-CoV-2 intracellular replication also involves the cell nucleus by active transport of viral nucleoprotein through the nuclear pore complex using $\alpha / \beta 1$ importin complex (GTPase $\rightarrow$ GTP $\rightarrow$ intranuclear transport $\rightarrow$ GTP hydrolysis $\rightarrow$ GDP $+\mathrm{Pi} \rightarrow$ extranuclear transport) (Frieman, Yount, Heise, Kopecky-Bromberg, Palese \& Baric, 2007, Caly, Druce, Catton, Jans \& Wagstaff, 2020, Uddin, Zonder \& Azmi, 2020). Inside the nucleus, the GEF-Ran protein exchanges GDP for GTP, changing the conformation of Ran and releasing the nucleocapsid protein of the virus inside the nucleus. Free Ran-GTP and CAS-linked RanGTP _ protein related to cell apoptosis _ bind to free importin- $\alpha$ in the nucleus and act as an exportin, exporting this subunit to the cytoplasmic surface of the nuclear envelope (GTP hydrolysis in GDP); this active transport of molecules to the cell nucleus depends on the hydrolysis of two GTP molecules (Moore, 2001, Cavazza \& Vernos, 2016). Some proteins important for viral replication reach the cytoplasm through nucleocytoplasmic transport (Frieman, Yount, Heise, Kopecky-Bromberg, Palese \& Baric, 2007, Caly, Druce, Catton, Jans \& Wagstaff, 2020, Uddin, Zonder \& Azmi, 2020). Despite undergoing replication in the 
cytoplasm, the positive single-stranded RNA $\left(\mathrm{RNA}^{+}\right)$virus nucleocapsid protein is located in the nucleus or nucleolus of infected cells, usually at the beginning of the infectious cycle. After its translation to perform non-structural functions, the viral nucleocapsid protein returns to the cytoplasm and participates in the assembly of new virions (Tijms, van der Meer \& Snijder, 2002, Yoo, Wootton, Li, Song \& Rowland, 2003, Sato, Masuda, Miura, Yoneda \& Kai, 2006, Wulan, Heydet, Walker, Gahan \& Ghildyal, 2015). Recent computational models of localization of subcellular RNA, in silico, on the location properties of SARS-CoV-2 transcripts, revealed predicted transcription residency signals, specifically for the nucleolus and mitochondrial matrix (unique characteristics of SARS-CoV-2) (Wu, Fazal, Parker, Zou \& Chang, 2020).

\section{Response of the infected cell against viral replication, leading to the onset of a hyperinflammatory state}

The coronavirus infecting human affects the cell division of the host, blocking molecular transport in the nucleocytoplasmic direction by viral nucleocapsid proteins. The antiviral activity mediated by STAT1 (signal transducer and activator of transcription 1) in infected cell is inhibited by the accessory virus ORF6, by sequestering importin- $\alpha$ and - $\beta 1$ subunit in the membranes of the rough endoplasmic reticulum and the Golgi complex (Kopecky-Bromberg, Martínez-Sobrido, Frieman, Baric \& Palese, 2007). This inhibits or reduces the expression of antiviral genes by STAT1, even if intracellular an intracellular STAT signaling/transduction from receptor tyrosine kinases activated by and pro-inflammatory molecules such as interleukin (IL) -6 , interferon (IFN) $-\alpha$ (IFN- $\alpha$ ), IFN- $\gamma$, and growth factors as PDGF (platelet-derived growth factor) occurs (Wulan, Heydet, Walker, Gahan \& Ghildyal, 2015, Hiscox, Wurm, Wilson, Britton, Cavanagh \& Brooks, 2001, Wurm, Chen, Hodgson, Britton, Brooks \& Hiscox, 2001, Rowland, Chauhan, Fang, Pekosz, Kerrigan \& Burton, 2005, Timani et al., 2005). Gene expressions by STAT1 are related to cell viability and survival, and responses to pathogens (Baris et al., 2016). Most interferon stimulated genes possess binding sites for STAT- or IFN- regulatory factor transcription factor-mediated expression (Kent et al., 2002, Read, Obeid, Ahlenstiel \& Ahlenstiel, 2019).

PAMPs (pathogen associated molecular patterns) virus such as glycoproteins from the viral envelope (13 MHC-I and 3 MHC-II epitopes in SARS-CoV-2 Spike) and nucleic acids are recognized by cell surface and cytosolic pattern recognition receptors (TLR5/7/8 $\rightarrow$ innate immune), and endosomal toll-like receptors 7 and 8 (TLR7/8) that primarily bind viral nucleic acids $\left(\right.$ RNA $^{+}$) (Pande, Kawai \& Akira, 2014, Moreno-Eutimio, López-Macías \& Pastelin-Palacios, 2020, Noorimotlagh, Karami, Mirzaee, Kaffashian, Mami \& Azizi, 2020). Thus, the downstream signaling intermediates activate both inflammatory and innate immune transcription factors and induce expression of IFN- $\alpha$ and IFN- $\beta$, IFN- $\gamma$, and/or IFN- $\lambda$ s, by a signaling cascade resulting in STAT1 and STAT2 heterodimerizing and binding interferon regulatory factor 9 (IRF9). Its translocation into the nucleus is related to gene promoter transcription, followed by immune cell chemotaxis and activation, and antiviral mechanisms to inhibit viral replication in the host cells (Read, Obeid, Ahlenstiel \& Ahlenstiel, 2019). An association has been reported between ACE2 expression and IFN-stimulated canonical genes (ISGs) or components of the IFN signaling pathway, comparing ACE2 ${ }^{+}$and ACE2 ${ }^{-}$cells; both type I and type II IFNs induced ACE2 expression in human epithelial cells and keratinocytes. SARS-CoV-2 does not appear to induce type I, II or III interferons in infected human lung tissues, which suggests that ACE2 may not be increased in this organ in COVID-19 (Su \& Jiang, 2020, Ziegler et al., 2020). The coronavirus infections induced expression of IFN, activating canonical IFN-induced genes (ISGs) and ACE2 expression, and contributing to the viral infection and acute lung injury (Su \& Jiang, 2020).

SARS-CoV-2 uses ACE2 ectoenzyme (functional receptor) and TMPRSS2 to invade the host cell (endocytosis), followed by an acute respiratory distress syndrome (cytokine-related) induced by the hyper-activation of the transcription factor NF-кB, coactivated by STAT3 (Hirano \& Murakami, 2020). The serum level of angiotensin 2 increases, and its accumulation induces inflammatory cytokines such as TNF $\alpha$, IL-6 and metalloprotease 17 (ADAM17), followed by the activation of the IL-6 
amplifier (IL-6 AMP). The HIF (hypoxia inducible factor) transcription factor family activates specific genes related to cellular oxygen homeostasis, and also participates in the pathogenesis of viral infection by coronavirus (Caly, Druce, Catton, Jans \& Wagstaff, 2020). The nuclear import pathway is under-regulated by the nuclear accumulation of importin- $\alpha$ and by the underregulation of importin- $\beta$ in response to stimuli such as oxidative stress and thermal shock stress (Kodiha, Chu, Matusiewicz \& Stochaj, 2004, Miyamoto et al., 2004). Hypoxia results in nuclear accumulation of HIF-1 $\alpha$ (Caly, Wagstaff \& Jans, 2012). The nuclear import of HIF proteins (HIF-1 $\alpha$, HIF- $2 \alpha$ and HIF-1 $\beta$ ) is triggered by the $\alpha / \beta 1$ importin complex [subfamily $\alpha$ (isoforms $\alpha 1, \alpha 3, \alpha 5$ and $\alpha 7)$ ] (Fagerlund, Kinnunen, Köhler, Julkunen \& Melén, 2005). During coronavirus viral replication and low oxygen saturation, HIF-mediated cell homeostasis can be compromised and result in cell death/lysis and tissue damage, related to the hyperinflammatory response (oxidative stress, cytokine storm, enzymatic degradation and other factors) (Hirano \& Murakami, 2020).

\section{Immunoinflammatory response}

The SARS-CoV-2 infected host cell undergoes pyroptosis and releases molecular patterns associated with damage cytopathic virus _, releasing high levels of IL-1 $\beta$ (Huang et al., 2020). Thus, ATP, nucleic acids and ASC oligomers are recognized by neighboring cells (epithelium, endothelium and macrophages) by the damage-associated molecular patterns (DAMPs), stimulating the release of pro-inflammatory cytokines and chemokines [IL-6, IP-10, macrophage inflammatory protein $1 \alpha$ (MIP1 $\alpha)$, MIP1 $\beta$ and MCP1]. Monocytes, macrophages and T cells promote additional inflammation at the site of infection, increasing IFN- $\gamma$ levels and promoting a pro-inflammatory feedback loop. Cumulative immune cells and chronic inflammation lead to overproduction of these cytokines and tissue damage. The resulting cytokine storm and non-neutralizing antibodies produced by B cells circulate to other organs, causing/exacerbating damage to various organs (Tay, Poh, Rénia, MacAry \& Ng, 2020)

ACE2 is high expressed in different tissues and organs as lung (especially type II pneumocytes and endothelium), gut (absorbent enterocytes), colon, ileum, kidney, gallbladder, heart muscle, epididymis, breast, ovary, stomach, bile duct, liver, oral cavity, lung, thyroid, esophagus, bladder, breast, uterus, prostate, pancreas, cerebellum, as well as calyx secreting cells in the nasal and sinus tissue (Yuki, Fujiogi \& Koutsogiannaki, 2020, Su \& Jiang, 2020, Hamming, Timens, Bulthui, Lely, Navis \& van Goor, 2004, Xu et al., 2020). Double positive cells ACE2 and TMPRSS2 are likely targets for SARS-CoV-2 (Su \& Jiang, 2020). Zou et al. (2020) reported a single-cell RNA-seq data analysis on the receptor ACE2 expression. The authors identified the organs at risk to SARS-CoV-2 infection, and located specific cell types (e.g. type II alveolar cells (AT2), myocardial cells, proximal tubule cells of the kidney, ileum and esophagus epithelial cells, and bladder urothelial cells), which are vulnerable to 2019-nCoV infection.

Therefore, the loss of homeostasis of the renin-angiotensin system and the systemic spread of the virus may interfere with other organs and systems, probably including the periodontium, as ACE2, ET-1 and TNF- $\beta$ have also been correlated with inflammatory processes in periodontal tissues (Hollá, Fassmann, Vašků, Znojil, Vaněk \& Vácha, 2001, Gürkan et al., 2009, Santos et al., 2009, Santos et al., 2015, Rodrigues, Barbirato, Luiz, Scharfstein, Salles \& Feres-Filho, 2016). In addition, the ACE2 ectoenzyme expressed in arterial and venous endothelial cells has important protective effects (angiotensin 1-7 mediated), including targeted anti-inflammatory drugs. ACE2 has been shown to regulate the renin-angiotensin system (Kuba, Imai \& Penninger, 2006). Therefore, a reduction in ACE2 function after SARS-CoV-2 infection could influence blood pressure and fluid/electrolyte balance and enhance inflammation and vascular permeability in the airways (Tay, Poh, Rénia, MacAry \& Ng, 2020). 
The ACE2/angiotensin 1-7/Mas receptor axis was related to alveolar bone remodeling and decreased alveolar bone loss by improving the osteoblast/osteoclast ratio and reducing IL-6 expression (Queiroz-Junior, 2019). Therefore, in SARS-CoV-2 infection, ACE2 availability decreases and systemic complications can occur, mainly cardiovascular and metabolic diseases (Leisman, Deutschman \& Legrand, 2020, Merad \& Martin, 2020). The cytokine storm intensifies the homeostatic imbalance throughout the body and may interfere with the bidirectional immunoinflammatory relationship between periodontal diseases and systemic conditions (Hollá, Fassmann, Vašků, Znojil, Vaněk \& Vácha, 2001, Kornman, 2008, Nakamura, HasegawaNakamura, Sakoda, Matsuyama \& Noguchi, 2011, Cekici, Kantarci, Hasturk \& Van Dyke, 2002, Hajishengallis, 2014, Hajishengallis \& Sahingur, 2014, Konkel, O'Boyle \& Krishnan, 2019, Pan, Wang \& Chen, 2019). The SARS-CoV-2-ACE2 bond can increase permeability, inflammation and microbial transmission by bacteremia or endotoxemia, in addition to dysbiosis. The hyperinflammatory response affects the cardiopulmonary system leading to endothelial dysfunction, vascular remodeling, pulmonary dysfunction and superinfections (viral and bacterial). Bacteremia, endotoxemia and a cytokine storm stimulate the production of immature megakaryocytes in the bone marrow and the activation of microglia in the paraventricular nucleus of the hypothalamus. The reduction in ACE2 associated with an increase in angiotensin II and angiotensin 1-7 affects important tissues and organs (Figure 1).

Figure 1: Compromise of homeostasis in different systems of the human body potentially related to periodontal diseases.

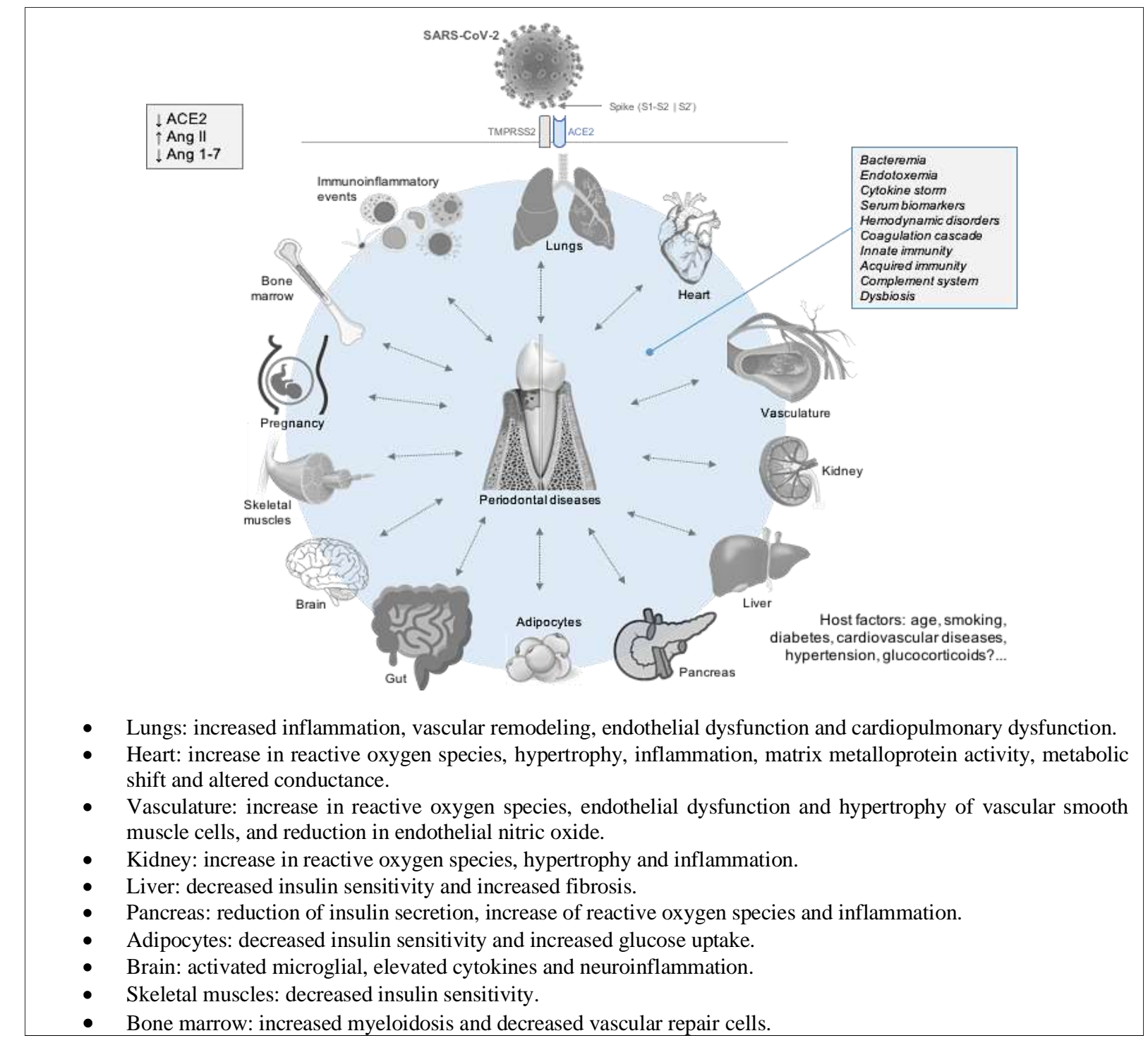
Source: Authors. 
In a systematic review, Smith et al. (2020) reported maternal and neonatal outcomes associated with COVID-19 infection, showing $63.8 \%$ of premature births, $61.1 \%$ of fetal distress, $76.9 \%$ of in-neonatal intensive care units and $42.8 \%$ low birth weight between 92 pregnant women with COVID-19 (67.4\% were symptomatic); $80 \%$ needed cesarean section. The main chronic non-communicable diseases correlated with COVID-19 are hypertension (21.1 \%; 95 \% CI, 13.0-27.2), diabetes mellitus (9.7\%; $95 \%$ CI, 7.2-12.2), cardiovascular diseases (8.4\%; $95 \%$ CI, 3.8-13.8) and respiratory disease (1.5\%; $95 \%$ CI, 0.9-2.1). Comparing severe and non-severe patients, the combined odds ratio of hypertension, respiratory system disease and cardiovascular disease were 2.36 (95 \% CI, 1.46-3.83), 2.46 (95\% CI, 1.76-3.44) and 3.42 (95\% CI, 1.88-6.22), respectively (Yang et al., 2020).

Abnormalities of laboratory parameters were observed in hospital patients with COVID-19 such as glucose, albumin, aspartate aminotransferase, lipase, creatine kinase, lactate dehydrogenase, urea, creatinine, high-sensitive cardiac troponin I, prothrombin time/International Normalized Ratio, activated partial thromboplastin time, procalcitonin, D-dimer, C-reactive protein, ferritin, hemoglobin, leukocytes, neutrophil and lymphocyte count, and neutrophil/lymphocyte ratio and peak platelet/lymphocyte ratio (Bonetti et al., 2020, Huang, Pranata, Lim, Oehadian \& Alisjahbana, 2020, Terpos et al., 2020, Zhang, Hou, Li \& Li, 2020). The inflammatory biomarkers C-reactive protein and IL-6 are increased in COVID-19 patients' blood (Terpos et al., 2020, Zhang, Hou, Li \& Li, 2020, Kermali, Khalsa, Pillai, Ismail \& Harky, 2020).

The systemic interactions of COVID-19 with obesity, diabetes mellitus, metabolic syndrome, hypertension, cerebrovascular and cardiovascular diseases, acute kidney injury, chronic liver diseases, chronic kidney and liver diseases, maternal and perinatal results can be confirmed in blood biomarkers (Ali et al., 2020, Chen et al., 2020, Huang, Lim \& Pranata, 2020, Malik, Ravindra, Attri, Bhadada \& Singh, 2020, Mantovani, Beatrice \& Dalbeni, 2020, Pranata, Huang \& Lim, 2020, Zaigham \& Andersson, 2020).

Patients with COVID-19 and acute respiratory distress syndrome may have lower levels of serum D-dimer and activated partial thomboplastin time, and higher levels of fibrinogen, antithrombin, prothrombin time and platelet count than non-COVID19 patients with acute respiratory distress syndrome (Helms et al., 2020). Viral pulmonary sepsis can lead to vasoconstriction and thrombotic events potentially related to myocardial infarction and necrosis of the renal and hepatic tissues (Li et al., 2020).

PAMPs recognition receptors such as TLR4 and TLR7, DAMPs and cytokines (IL-6 and CCL2) activate blood monocytes that express tissue factor (TF) in the cell membrane. Cytokines (IL-6 and TNF) and viral particles stimulate endothelial cells to produce chemo-attractants of monocytes and adhesion molecules (P-selectin) and expose TF in the lumen, which recruits monocytes activated endothelial cells, TF and microvesicles derived from activated monocytes stimulate fibrin deposition and blood clotting (extrinsic coagulation pathway). Extracellular neutrophil traps (NETs) activate the coagulation contact pathway and bind and activate platelets (amplification of coagulation). In COVID-19, the inhibitor of the tissue factor pathway (TFPI), antithrombin and protein C (endogenous anticoagulant pathways) are reduced. The von Willebrand factor and the exposure of collagen from endothelial injury lead to the accumulation of platelets and fibrin and stimulate the intrinsic/contact coagulation pathway (Merad \& Martin, 2020).

Thrombosis and pulmonary embolism in severe forms of COVID-19 are correlated with elevated levels of D-dimer and fibrinogen and abnormalities in the endothelium related to vasodilation, fibrinolysis and anti-aggregation. Significant endothelial lesions compromise thrombotic regulation leading to a hypercoagulable condition (Wang, Hao, Leeper \& Zhu, 2018). Endothelial cells express the ACE2 ectoenzyme and correspond to one third of lung cells. The increase in ACE2-mediated microvascular permeability, inflammatory events and microbial challenge (viral infections and/or bacterial superinfections) can potentiate coronavirus infection, bacteremia, endotoxemia, hyperinflammatory status and systemic complications in multiple 
tissues and organs (Yuki, Fujiogi \& Koutsogiannaki, 2020, Yuki K, Fujiogi M, Koutsogiannaki et al., 2008, Sluimer et al., 2008, Zeng et al., 2012).

Pulmonary injury lesions in SARS-CoV-2 infection occur, in part, because ACE2 is highly expressed on the apical side of pulmonary epithelial cells in the alveolar space. The main cellular components of innate immunity in the lungs are epithelial cells, alveolar macrophages located on the apical side of the epithelium and subepithelial dendritic cells (Yoshikawa, Hill, Li, Peters \& Tseng, 2009). These cells present the antigen (coronavirus) to T cells in the lymph nodes by phagocytosis of apoptotic cells infected by the virus, through PAMPs (Fujimoto, Pan, Takizawa \& Nakanishi, 2000, Channappanavar, Zhao \& Perlman, 2014). ACE2 expression in dendritic (splenic) cells and alveolar macrophages is limited, however, the SARS-CoV virus can bind to dendritic-cell specific intercellular adhesion molecule-3-grabbing nonintegrin (DC-SIGN) and DC-SIGN-related protein (DC-SIGNR, L-SIGN), highly expressed in dendritic cells and macrophages (Jeffers et al., 2004, Marzi et al., 2004, Yang et al., 2004). Therefore, it is possible that these antigen-presenting cells may be infected with coronary viruses, in addition to phagocyting them. $\mathrm{CD}^{+}$cells activate $\mathrm{B}$ cells and promote the production of antibodies specific to the virus (IgM antibodies (recent exposure or acute events) and IgG (delayed immunity)). CD8 ${ }^{+} \mathrm{T}$ cells can kill infected viral cells, especially in the early stages of the disease (Yuki, Fujiogi \& Koutsogiannaki, 2020).

Severe forms of COVID-19 result in lymphopenia and reduction of peripheral blood T cells (lymphocyte count) (Gu et al., 2005, Frater, Zini, d'Onofrio \& Rogers, 2020, Qin et al., 2020, Wilk et al., 2020). Increased plasma concentrations of proinflammatory cytokines, such as interleukin (IL) -1 $\beta$, IL-6, IL-8, IL-10, IL-17, interferon gamma-induced protein (IP) -10, granulocyte colony-stimulating factor (G-CSF), granulocyte-macrophage colony-stimulating factor (GM-CSF), monocyte chemotherapy activating protein 1 (MCP1), inflammatory macrophage protein (MIP) $1 \alpha$, tumor necrosis (TNF) - $\alpha$, and mediators that are targeted in IMIDs (immune-mediated inflammatory diseases) (Schett, Sticherling \& Neurath, 2020, Huang et al., 2020, Qin et al., 2020, Wilk et al., 2020). IL-6 levels correlate positively with the severity of the disease. Increased expression of CD69, $\mathrm{CD} 38$ and $\mathrm{CD} 44$ indicates that $\mathrm{CD} 4^{+}$and $\mathrm{CD} 8^{+}$cells have been activated. Higher percentage of $\mathrm{Tm} 3^{+} \mathrm{PD}-1^{+}$subsets and $\mathrm{NK}$ group 2 member A (NKG2A) in $\mathrm{CD}^{+}$and $\mathrm{CD}^{+}$T cells showed that T cells were also depleted (Zheng et al., 2020). Pathogenic $\mathrm{CD}^{+} \mathrm{T}$ cells with co-expressing interferon (IFN) $-\gamma$ and granulocyte-macrophage colony stimulating factor (GM-CSF) have been observed in patients with COVID-19 with severe disease (Wilk et al., 2020). GM-CSF helps cell differentiation in innate immunity, increases the function of T cells and release of IL-6, and can be associated with major tissue damage (Yuki, Fujiogi \& Koutsogiannaki, 2020, Croxford et al., 2015, Huang et al., 2019). Serum levels of TNF, IL-6 and IL-10 negatively correlated with T cell count (Diao et al., 2020).

SARS-CoV-infected lung epithelial cells produce IL-6 and IL-8. IL-8-mediated neutrophil chemotaxis increases the number of innate and adaptive immune inflammatory cells in the lungs of critically ill patients with COVID-19 (Tian et al., 2020 , $\mathrm{Xu}$ et al, 2020). The innate neutrophil-mediated immune response is correlated with lung injury, (Young et al., 2004, Koutsogiannaki, Shimaoka \& Yuki, 2019, Fang et al., 2012) while the adaptive immune response mediated by CD8 ${ }^{+} \mathrm{T}_{\text {cells }}$ (primary cytotoxic) and pathological cytotoxic $\mathrm{T}$ cells derived from $\mathrm{CD} 4^{+} \mathrm{T}$ cells kills the virus, cause lung injury, and recruit monocytes $\left(\mathrm{CD} 14^{+} \mathrm{CD} 16^{+}\right)$by GM-CSF. These inflammatory monocytes showed high expression of IL-6 and increased the systemic inflammatory response (Yuki, Fujiogi \& Koutsogiannaki, 2020, Fang et al., 2012, Small et al., 2001).

ACE2 is also expressed in internal lymphoid cells (ILC) 2 and ILC3, responsible for mucosal homeostasis. Approximately $95 \%$ of lung ILCs are Natural Killer (NK) cells, type ILC1. The relationship of coronaviruses infection with ILC2 and ILC3 cells has not yet been defined (Yuki, Fujiogi \& Koutsogiannaki, 2020).

COVID-19 causes high levels of circulating pro-inflammatory cytokines and chemokines, such as IL-6, IFN $\gamma$, MCP1 and IP-10, (Zhang et al., 2020, Huang et al., 2020) related to a polarized response by helper T cells 1 (T $\mathrm{T}_{\mathrm{H}}$ ) (Huang et al., 2005). 
These signaling molecules attract monocytes and T lymphocytes to the site of infection, but not neutrophils (Tian et al., 2020, $\mathrm{Xu}$ et al., 2020). The recruitment of immune blood cells and the lymphocytic infiltration in the lungs result in lymphopenia and an increase in the neutrophil-lymphocyte ratio in patients with COVID-19 (Hamming et al., 2004, Qin et al., 2020).

Critical COVID-19 patients admitted to the intensive care unit show dysfunctional immune responses and elevated plasma levels of IL-2, IL-6, IL-7, IL-7, IL-10, G -CSF, IP-10, MCP1, MIP1 $\alpha$ and TNF. IL-6 levels increase according to the severity of the disease and are correlated with cases of death (Huang et al., 2020, Zhou et al., 2020, Zhou et al., 2020). In addition, these patients have a population of FCN1 macrophages derived from highly inflammatory monocytes in the bronchoalveolar region (Chua et al., 2020) and a significantly higher percentage of $\mathrm{CD} 14^{+} \mathrm{CD} 16^{+}$inflammatory monocytes in the peripheral blood (Wilk et al., 2020). Cytokines secreted by these monocytes like MCP-1, IP-10 and MIP1 $\alpha$ contribute to the cytokine storm (Tay, Poh, Rénia, MacAry \& Ng, 2020).

As in SARS-CoV infection, it is possible that SARS-CoV-2 influences the stages of the interferon signaling pathway and prevents the recognition of viral RNA for PRR, (Wilk et al., 2020, Siu, Chan, Kok, Chiu-Yat Woo \& Jin, 2014) by preventing

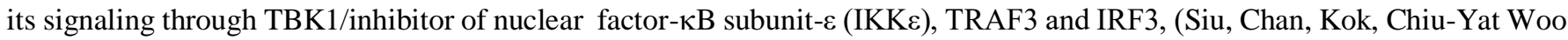
\& Jin, 2014, Frieman, Ratia, Johnsto, Mesecar \& Baric, 2009) resulting in an antagonism of the interferon responses downstream through STAT1 (Frieman et al., 2007) and inhibiting the host protein translation by mRNA degradation (Narayanan et al., 2008). This condition helps in viral replication and leads to aberrant inflammatory responses from pyroptosis. The species of virus, protease and reactive oxygen are associated with local tissue damage [diffuse alveolar damage (desquamation of alveolar cells), formation of hyaline membrane and pulmonary edema] (Tian et al., 2020, Xu et al., 2020). As a result, in addition to reducing oxygen saturation, secondary infections can occur (Tay, Poh, Rénia, MacAry \& Ng, 2020).

The cytokine storm is related to local tissue damage and negative effects in the body, reaching septic shock and multiple organ failure associated with elevated levels of TNF. The dysfunctional immune response that causes pathology and also fails to successfully eradicate pathogens is more evident in people with comorbidities. It is still controversial whether the persistence of the virus is necessary to cause damage and loss of function in tissues and organs (Tay, Poh, Rénia, MacAry \& Ng, 2020, Zhou et al., 2020). Viral infection of immune cells by SARS-CoV, even if it is not productive, leads to a hyperinflammatory response of monocytes and macrophages, for example; (Cheung et al., 2005, Law et al., 2005, Tseng, Perrone, Zhu, Makino \& Peters, 2005, Yilla et al., 2005) the same should occur with exposure to SARS-CoV-2 (Tay, Poh, Rénia, MacAry \& Ng, 2020).

The acute respiratory distress syndrome associated with impaired lung function in COVID-19 was attributed to a nonadaptive immune response (Guan et al., 2020). Vascular and cellular events of inflammation mediated by pro-inflammatory cytokines produced by immune cells resident in the lung lead to the leakage of neutrophils and monocytes from the blood into the bronchi, breaking through the air-blood barrier and causing damage to epithelial cells and local vascular endothelial cells (express ACE2); vascular endothelial injury may result in thrombotic microangiopathies. In the innate immune response to viruses, the complement system appears to induce pro-inflammatory responses via activation of the C3 component (observed in SARS-CoV-2 infections), associated with the acute respiratory distress syndrome (Mastellos, Ricklin \& Lambris, 2019, Li et al., 2020). These findings did not occur in mice with C3 deficiency infected with SARS-CoV, where the neutrophilic infiltrate and the levels of IL-6 in the lung were significantly reduced (Gralinski et al., 2018). The immunoinflammatory events previously described for other coronavirus infections can be repeated in the pathogenesis of COVID-19; however, clinical data on the role of complement activation associated with SARS-CoV-2 are still limited. Despite this, lung biopsies from patients with COVID19 confirmed complement activation with a generation of $\mathrm{C} 3 \mathrm{a}$ and deposition of $\mathrm{C} 3$ fragments, in addition to a significant increase in serum C5a levels. Treatment of COVID-19 with anti-C5a antibody (well-established axis C5a-C5aR in the 
pathophysiology of acute respiratory distress syndrome) resulted in an increase in pulmonary oxygenation and a decrease in systemic inflammation and in the clinical improvement of patients (Campbell CM, Kahwash, 2020, Risitano et al., 2020).

\section{Final Considerations}

The affinity of SARS-CoV-2 for ACE2 and the complications of loss of homeostasis of the renin-angiotensin system result in decompensations or deregulations of different axes compromising metabolic, cardiorespiratory, renal and hepatic control. The thrombotic potential and the hyperinflammatory cell response potentiate this imbalance and can compromise function or lead to injuries and multiple organ failure. Based on the pathogenesis of coronavirus infections, this theoretical essay proposes the conceptual hypothesis that infection by SARS-CoV-2, especially in cases of severe COVID-19, is able to modify the natural history of diseases, the relationships or interactions between the different systems and pathologies, and the consequences of their treatments.

New experimental studies, epidemiological studies, epigenetic, immunoinflammatory and microbiological characterization, and the comparison of the results of clinical trials during or after the COVID-19 pandemic with the results of the pre-pandemic period, will contribute to establish the impacts of SARS-CoV-2 infection in periodontal medicine.

\section{Acknowledgments}

The authors acknowledge the financial support provided by the following Brazilian funding agencies: Conselho Nacional de Desenvolvimento Científico e Tecnológico (CNPq), Coordenação de Aperfeiçoamento de Pessoal de Nível Superior (CAPES), and Fundação de Amparo à Ciência e Tecnologia do Estado de Pernambuco (FACEPE). We would also like to thank the Federal University of Rio de Janeiro and Federal University of Pernambuco for all the support.

\section{References}

Ali H., Daoud A., Mohamed M. M., Salim S. A., Yessayan L., Baharani J., Murtaza A., Rao V. \& Soliman K. M. Survival rate in acute kidney injury superimposed COVID-19 patients: a systematic review and meta-analysis. Ren Fail. 2020,42(1):393-397. https://doi.org/10.1080/0886022X.2020.1756323.

Baris S., Alroqi F., Kiykim A., Karakoc-Aydiner E., Ogulur I., Ozen A., Charbonnier L.M., Bakır M., Boztug K., Chatila T.A. \& Barlan I. B. Severe EarlyOnset Combined Immunodeficiency due to Heterozygous Gain-of-Function Mutations in STAT1. J Clin Immunol. 2016,36(7):641-8. https://doi.org/10.1007/s10875-016-0312-

Bertram S., Glowacka I., Müller M. A., Lavender H., Gnirss K., Nehlmeier I., Niemeyer D., He Y., Simmons G., Drosten C., Soilleux E. J., Jahn O., Steffen I. $\&$ Pöhlmann S. Cleavage and activation of the severe acute respiratory syndrome coronavirus spike protein by human airway trypsin-like protease. $J$ Virol. 2011,85(24):13363-72. https://doi.org/10.1128/JVI.05300-11.

Bonetti G., Manelli F., Patroni A., Bettinardi A., Borrelli G., Fiordalisi G., Marino A., Menolfi A., Saggini S., Volpi R., Anesi A. \& Lippi G.. Laboratory predictors of death from coronavirus disease 2019 (COVID-19) in the area of Valcamonica, Italy. Clin Chem Lab Med. 2020,25,58(7):1100-1105. https://doi.org/10.1515/cclm-2020-0459.

Caly L., Druce J. D., Catton M. G., Jans D. A. \& Wagstaff K. M. The FDA-approved drug ivermectin inhibits the replication of SARS-CoV-2 in vitro. Antiviral Res. 2020,178:104787. https://doi.org/10.1016/j.antiviral.2020.104787.

Caly L., Wagstaff K. M. \& Jans D. A. Nuclear trafficking of proteins from RNA viruses: potential target for antivirals? Antiviral Res. 2012,95(3):202-6. https://doi.org/10.1016/j.antiviral.2012.06.008.

Campbell C. M. \& Kahwash R. Will Complement Inhibition Be the New Target in Treating COVID-19-Related Systemic Thrombosis? Circulation. 2020,141(22):1739-1741. https://doi.org/10.1161/CIRCULATIONAHA.120.047419.

Cao W. \& Li T. (2020). COVID-19: towards understanding of pathogenesis. Cell Res. 2020,30(5):367-369. https://doi.org/10.1038/s41422-020-0327-4.

Cavazza T. \& Vernos I. The RanGTP Pathway: From Nucleo-Cytoplasmic Transport to Spindle Assembly and Beyond. Front Cell Dev Biol. $2016,11,3: 82$. https://doi.org/10.3389/fcell.2015.00082.

Cekici A., Kantarci A., Hasturk H. \& Van Dyke T. E. Inflammatory and immune pathways in the pathogenesis of periodontal disease. Periodontol 2000. 2014,64(1):57-80. https://doi.org/10.1111/prd.12002. 
Channappanavar R., Zhao J. \& Perlman S. T cell-mediated immune response to respiratory coronaviruses. Immunol Res. 2014,59(1-3):118-28. https://doi.org/10.1007/s12026-014-8534-z.

Chen Y., Liu Q. \& Guo D.. Emerging coronaviruses: Genome structure, replication, and pathogenesis. J Med Virol. 2020,92(4):418-423. https://doi.org/10.1002/jmv.25681.

Chen Y. T., Shao S. C., Hsu C. K., Wu I. W., Hung M. J. \& Chen Y. C. Incidence of acute kidney injury in COVID-19 infection: a systematic review and metaanalysis. Crit Care. 2020,16,24(1):346. https://doi.org/10.1186/s13054-020-03009-y.

Cheung C. Y., Poon L. L., Ng I. H., Luk W., Sia S. F., Wu M. H., Chan K. H., Yuen K. Y., Gordon S., Guan Y. \& Peiris J. S. Cytokine responses in severe acute respiratory syndrome coronavirus-infected macrophages in vitro: possible relevance to pathogenesis. $J$ Virol. 2005,79(12):7819-26. https://doi.org/10.1128/JVI.79.12.7819-7826.2005.

Chua R. L., Lukassen S., Trump S., Hennig B. P., Wendisch D., Pott F., Debnath O., Thürmann L., Kurth F., Völker M. T., Kazmierski J., Timmermann B., Twardziok S., Schneider S., Machleidt F., Müller-Redetzky H., Maier M., Krannich A., Schmidt S., Balzer F., Liebig J., Loske J., Suttorp N., Eils J., Ishaque N., Liebert U. G., von Kalle C., Hocke A., Witzenrath M., Goffinet C., Drosten C., Laudi S., Lehmann I., Conrad C., Sander L. E. \& Eils R. COVID-19 severity correlates with airway epithelium-immune cell interactions identified by single-cell analysis. Nat Biotechnol. 2020,38(8):970-979. https://doi.org/10.1038/s41587-020-0602-4.

Committee on Taxonomy of Viruses. The species Severe acute respiratory syndrome-related coronavirus: classifying 2019 -nCoV and naming it SARS-CoV-2. Nat Microbiol. 2020,5(4):536-544. https://doi.org/10.1038/s41564-020-0695-z.

Croxford A. L., Lanzinger M., Hartmann F. J., Schreiner B., Mair F., Pelczar P., Clausen B. E., Jung S., Greter M. \& Becher B. The Cytokine GM-CSF Drives the Inflammatory Signature of CCR2+ Monocytes and Licenses Autoimmunity. Immunity. 2015,43(3):502-14. https://doi.org/10.1016/j.immuni.2015.08.010.

Cui J., Li F. \& Shi Z. L. Origin and evolution of pathogenic coronaviruses. Nat Rev Microbiol. 2019,17(3):181-192. https://doi.org/10.1038/s41579-018-01189

Diao B., Wang C., Tan Y., Chen X., Liu Y., Ning L., Chen L., Li M., Liu Y., Wang G., Yuan Z., Feng Z., Zhang Y., Wu Y. \& Chen Y. Reduction and Functional Exhaustion of T Cells in Patients With Coronavirus Disease 2019 (COVID-19). Front Immunol. 2020,1,11:827. https://doi.org/10.3389/fimmu.2020.00827.

Fagerlund R., Kinnunen L., Köhler M., Julkunen I. \& Melén K. NF-\{kappa\}B is transported into the nucleus by importin \{alpha\}3 and importin \{alpha\}4. $J$ Biol Chem 2005,22,280(16):15942-51. https://doi.org/10.1074/jbc.M500814200.

Fang M., Siciliano N. A., Hersperger A. R., Roscoe F., Hu A., Ma X., Shamsedeen A. R., Eisenlohr L. C. \& Sigal L. J. Perforin-dependent CD4+ T-cell cytotoxicity contributes to control a murine poxvirus infection. Proc Natl Acad Sci USA. 2012,109(25):9983-8. https://doi.org/10.1073/pnas.1202143109.

Fehr A.R. \& Perlman S. Coronaviruses: an overview of their replication and pathogenesis. Methods Mol Biol. 2015,1282:1-23. https://doi.org/10.1007/978-14939-2438-7_1.

Frater J. L., Zini G., d'Onofrio G. \& Rogers H.J. COVID-19 and the clinical hematology laboratory. Int J Lab Hematol. 2020,42,Suppl1:11-18. https://doi.org/10.1111/ijlh.13229.

Frieman M., Ratia K., Johnston R. E., Mesecar A. D. \& Baric R. S. Severe acute respiratory syndrome coronavirus papain-like protease ubiquitin-like domain and catalytic domain regulate antagonism of IRF3 and NF-kappaB signaling. J Virol. 2009,83(13):6689-705. https://doi.org/10.1128/JVI.02220-08.

Frieman M., Yount B., Heise M., Kopecky-Bromberg S. A., Palese P. \& Baric R. S. Severe acute respiratory syndrome coronavirus ORF6 antagonizes STAT1 function by sequestering nuclear import factors on the rough endoplasmic reticulum/Golgi membrane. J Virol. 2007,81(18):9812-24. https://doi.org/10.1128/JVI.01012-07.

Fujimoto I., Pan J., Takizawa T. \& Nakanishi Y. Virus clearance through apoptosis-dependent phagocytosis of influenza A virus-infected cells by macrophages. J Virol. 2000,74(7):3399-403. https://doi.org/10.1128/jvi.74.7.3399-3403.2000.

Gheblawi M., Wang K., Viveiros A., Nguyen Q., Zhong J. C., Turner A. J., Raizada M. K., Grant M. B. \& Oudit G. Y. Angiotensin-Converting Enzyme 2: SARS-CoV-2 Receptor and Regulator of the Renin-Angiotensin System: Celebrating the 20th Anniversary of the Discovery of ACE2. Circ Res. 2020,8,126(10):1456-1474. https://doi.org/10.1161/CIRCRESAHA.120.317015.

Glowacka I., Bertram S., Müller M. A., Allen P., Soilleux E., Pfefferle S., Steffen I., Tsegaye T. S., He Y., Gnirss K., Niemeyer D., Schneider H., Drosten C. \& Pöhlmann S. Evidence that TMPRSS2 activates the severe acute respiratory syndrome coronavirus spike protein for membrane fusion and reduces viral control by the humoral immune response. J Virol. 2011,85(9):4122-34. https://doi.org/10.1128/JVI.02232-10.

Gralinski L. E. \& Menachery V. D. Return of the Coronavirus: 2019-nCoV. Viruses. 2020,24,12(2):135. https://doi.org/10.3390/v12020135.

Gralinski L. E., Sheahan T. P., Morrison T. E., Menachery V. D., Jensen K., Leist S. R., Whitmore A., Heise M. T. \& Baric R. S. Complement Activation Contributes to Severe Acute Respiratory Syndrome Coronavirus Pathogenesis. mBio. 2018,9(5):e01753-18. https://doi.org/10.1128/mBio.01753-18.

Gu J., Gong E., Zhang B., Zheng J., Gao Z., Zhong Y., Zou W., Zhan J., Wang S., Xie Z., Zhuang H., Wu B., Zhong H., Shao H., Fang W., Gao D., Pei F., Li X., He Z., Xu D., Shi X., Anderson V.M., Leong A.S.. Multiple organ infection and the pathogenesis of SARS. J Exp Med. $2005,202(3): 415-24$. https://doi.org/10.1084/jem.20050828.

Guan W. J., Ni Z. Y., Hu Y., Liang W. H., Ou C. Q., He J. X., Liu L., Shan H., Lei C. L., Hui D. S. C., Du B., Li L. J., Zeng G., Yuen K. Y., Chen R. C., Tang C. . L, Wang T., Chen P. Y., Xiang J., Li S. Y., Wang J. L., Liang Z. J., Peng Y. X., Wei L., Liu Y., Hu Y. H., Peng P., Wang J. M., Liu J. Y., Chen Z., Li G., Zheng Z. J., Qiu S. Q., Luo J., Ye C. J., Zhu S. Y., Zhong N. S., China Medical Treatment Expert Group for Covid-19. Clinical Characteristics of Coronavirus Disease 2019 in China. N Engl J Med. 2020,382(18):1708-1720. https://doi.org/10.1056/NEJMoa2002032. 
Gürkan A., Emingil G., Saygan B. H., Atilla G., Köse T., Baylas H. \& Berdeli A. Renin-angiotensin gene polymorphisms in relation to severe chronic periodontitis. J Clin Periodontol. 2009,36(3):204-11. https://doi.org/10.1111/j.1600-051X.2008.01379.x.

Hadjadj J., Yatim N., Barnabei L., Corneau A., Boussier J., Smith N., Péré H., Charbit B., Bondet V., Chenevier-Gobeaux C., Breillat P., Carlier N., Gauzit R., Morbieu C., Pène F., Marin N., Roche N., Szwebel T. A., Merkling S. H., Treluyer J. M., Veyer D., Mouthon L., Blanc C., Tharaux P. L., Rozenberg F., Fischer A., Duffy D., Rieux-Laucat F., Kernéis S. \& Terrier B. (2020). Impaired type I interferon activity and inflammatory responses in severe COVID-19 patients. Science. 2020,369(6504):718-724. https://doi.org/10.1126/science.abc6027.

Hajishengallis G. \& Sahingur S. E. Novel inflammatory pathways in periodontitis. Adv Dent Res. 2014,26(1):23-9. https://doi.org/10.1177/0022034514526240. Hajishengallis G. Immunomicrobial pathogenesis of periodontitis: keystones, pathobionts, and host response. Trends Immunol. 2014,35(1):3-11. https://doi.org/10.1016/j.it.2013.09.001.

Hamming I., Timens W., Bulthuis M. L., Lely A. T., Navis G. \& van Goor H. Tissue distribution of ACE2 protein, the functional receptor for SARS coronavirus. A first step in understanding SARS pathogenesis. J Pathol. 2004,203(2):631-7. https://doi.org/10.1002/path.1570.

Helms J., Tacquard C., Severac F., Leonard-Lorant I., Ohana M., Delabranche X., Merdji H., Clere-Jehl R., Schenck M., Fagot Gandet F., Fafi-Kremer S., Castelain V., Schneider F., Grunebaum L., Anglés-Cano E., Sattler L., Mertes P. M., Meziani F. \& CRICS TRIGGERSEP Group (Clinical Research in Intensive Care and Sepsis Trial Group for Global Evaluation and Research in Sepsis). High risk of thrombosis in patients with severe SARS-CoV-2 infection: a multicenter prospective cohort study. Intensive Care Med. 2020,46(6):1089-1098. https://doi.org/10.1007/s00134-020-06062-x.

Henry B. M., de Oliveira M. H. S., Benoit S., Plebani M. \& Lippi G. (2020). Hematologic, biochemical and immune biomarker abnormalities associated with severe illness and mortality in coronavirus disease 2019 (COVID-19): a meta-analysis. Clin Chem Lab Med. 2020,58(7):1021-1028. https://doi.org/10.1515/cclm-2020-0369.

Hirano T. \& Murakami M.. COVID-19: A New Virus, but a Familiar Receptor and Cytokine Release Syndrome. Immunity. 2020,19,52(5):731-733. https://doi.org/10.1016/j.immuni.2020.04.003.

Hiscox J. A., Wurm T., Wilson L., Britton P., Cavanagh D. \& Brooks G. The coronavirus infectious bronchitis virus nucleoprotein localizes to the nucleolus. $J$ Virol. 2001,75(1):506-12. https://doi.org/10.1128/JVI.75.1.506-512.2001.

Hoffmann M., Kleine-Weber H., Schroeder S., Krüger N., Herrler T., Erichsen S., Schiergens T. S., Herrler G., Wu N. H., Nitsche A., Müller M. A., Drosten C. \& Pöhlmann S. SARS-CoV-2 Cell Entry Depends on ACE2 and TMPRSS2 and Is Blocked by a Clinically Proven Protease Inhibitor. Cell. 2020,16,181(2):271280.e8. https://doi.org/10.1016/j.cell.2020.02.052.

Hollá L. I., Fassmann A., Vašků A., Znojil V., Vaněk J. \& Vácha J. Interactions of Lymphotoxin $\alpha$ (TNF- $\beta$ ), Angiotensin-Converting Enzyme (ACE), and Endothelin-1 (ET-1) Gene Polymorphisms in Adult Periodontitis. J Periodontol. 2001,72(1):85-89. https://doi.org/10.1902/jop.2001.72.1.85.

Huang C., Wang Y., Li X., Ren L., Zhao J., Hu Y., Zhang L., Fan G., Xu J., Gu X., Cheng Z., Yu T., Xia J., Wei Y., Wu W., Xie X., Yin W., Li H., Liu M., Xiao Y., Gao H., Guo L., Xie J., Wang G., Jiang R., Gao Z., Jin Q., Wang J. \& Cao B. Clinical features of patients infected with 2019 novel coronavirus in Wuhan, China. Lancet. 2020,15,395(10223):497-506. https://doi.org/10.1016/S0140-6736(20)30183-5.

Huang H., Wang S., Jiang T., Fan R., Zhang Z., Mu J., Li K., Wang Y., Jin L., Lin F., Xia J., Sun L., Xu B., Ji C., Chen J., Chang J., Tu B., Song B., Zhang C., Wang F. S. \& Xu R. High levels of circulating GM-CSF+CD4+ T cells are predictive of poor outcomes in sepsis patients: a prospective cohort study. Cell Mol Immunol. 21h,16(6):602-610. https://doi.org/10.1038/s41423-018-0164-2.

Huang I., Lim M. A., Pranata R. . Diabetes mellitus is associated with increased mortality and severity of disease in COVID-19 pneumonia - A systematic review, meta-analysis, and meta-regression. Diabetes Metab Syndr. 2020,14(4):395-403. https://doi.org/10.1016/j.dsx.2020.04.018.

Huang I., Pranata R., Lim M. A., Oehadian A. \& Alisjahbana B. C-reactive protein, procalcitonin, D-dimer, and ferritin in severe coronavirus disease-2019: a meta-analysis. Ther Adv Respir Dis. 2020,14:1753466620937175. https://doi.org/10.1177/1753466620937175.

Huang K. J., Su I. J., Theron M., Wu Y. C., Lai S. K., Liu C. C. \& Lei H. Y. An interferon-gamma-related cytokine storm in SARS patients. J Med Virol. 2005,75(2):185-94. https://doi.org/10.1002/jmv.20255

Hui D. S., Azhar E., Madani T. A., Ntoumi F., Kock R., Dar O., Ippolito G., Mchugh T.D., Memish Z.A., Drosten C., Zumla A. \& Petersen E. The continuing 2019-nCoV epidemic threat of novel coronaviruses to global health - The latest 2019 novel coronavirus outbreak in Wuhan, China. Int J Infect Dis. 2020,91:264266. https://doi.org/10.1016/j.ijid.2020.01.009.

Jeffers S. A., Tusell S. M., Gillim-Ross L., Hemmila E. M., Achenbach J. E., Babcock G. J., Thomas W. D. Jr, Thackray L. B., Young M. D., Mason R. J., Ambrosino D. M., Wentworth D. E., Demartini J. C. \& Holmes K. V. CD209L (L-SIGN) is a receptor for severe acute respiratory syndrome coronavirus. Proc Natl Acad Sci USA. 2004,2,101(44):15748-53. https://doi.org/10.1073/pnas.0403812101.

Kent W. J., Sugnet C. W., Furey T. S., Roskin K. M., Pringle T. H., Zahler A. M. \& Haussler D. The human genome browser at UCSC. Genome Res. 2002,12(6):996-1006. https://doi.org/10.1101/gr.229102.

Kermali M., Khalsa R. K., Pillai K., Ismail Z. \& Harky A. The role of biomarkers in diagnosis of COVID-19 - A systematic review. Life Sci. $2020,1,254: 117788$. https://doi.org/10.1016/j.lfs.2020.117788.

Kim Y. H., Han M. E. \& Oh S. O. The molecular mechanism for nuclear transport and its application. Anat Cell Biol. 2017,50(2):77-85. https://doi.org/10.5115/acb.2017.50.2.77.

Koche, J. C. (2011). Fundamentos de metodologia científica. Petrópolis: Vozes. From: http://www.brunovivas.com/wpcontent/uploads/sites/10/2018/07/K\%C3\%B6che-Jos\%C3\%A9-Carlos0D0AFundamentos-de-metodologia-cient\%C3\%ADfica -_- teoria-da0D0Aci\% C3\% AAncia-e-inicia\% C3\% A7\% C3\% A3o-\% C3\% A0-pesquisa.pdf 
Kodiha M., Chu A., Matusiewicz N. \& Stochaj U. Multiple mechanisms promote the inhibition of classical nuclear import upon exposure to severe oxidative stress. Cell Death Differ. 2004,11(8):862-74. https://doi.org/10.1038/sj.cdd.4401432.

Konkel J. E., O'Boyle C. \& Krishnan S. Distal Consequences of Oral Inflammation. Front Immunol. 2019,10:1403. https://doi.org/10.3389/fimmu.2019.01403.

Kopecky-Bromberg S. A., Martínez-Sobrido L., Frieman M., Baric R. A. \& Palese P. Severe acute respiratory syndrome coronavirus open reading frame (ORF) 3b, ORF 6, and nucleocapsid proteins function as interferon antagonists. J Virol., 81(2):548-57. https://doi.org/10.1128/JVI.01782-06.

Kornman K.S. Mapping the pathogenesis of periodontitis: a new look. J Periodontol. 2008, 79(8):1560-8. https://doi.org/10.1902/jop.2008.080213.

Koutsogiannaki S., Shimaoka M. \& Yuki K. The Use of Volatile Anesthetics as Sedatives for Acute Respiratory Distress Syndrome. Transl Perioper Pain Med. 2019,6(2):27-38. https://doi.org/10.31480/2330-4871/084.

Kuba K., Imai Y. \& Penninger J.M. Angiotensin-converting enzyme 2 in lung diseases. Curr Opin Pharmacol. 6(3):271-6. https://doi.org/10.1016/j.coph.2006.03.001.

Lai C.C., Shih T.P., Ko W.C., Tang H.J. \& Hsueh P.R. Severe acute respiratory syndrome coronavirus 2 (SARS-CoV-2) and coronavirus disease-2019 (COVID19): The epidemic and the challenges. Int J Antimicrob Agents. 2020,55(3):105924. https://doi.org/10.1016/j.ijantimicag.2020.105924.

Law H.K., Cheung C.Y., Ng H.Y., Sia S.F., Chan Y.O., Luk W., Nicholls J.M., Peiris J.S. \& Lau Y.L. Chemokine up-regulation in SARS-coronavirus-infected, monocyte-derived human dendritic cells. Blood. 2005,106(7):2366-74. https://doi.org/10.1182/blood-2004-10-4166.

Leisman D.E., Deutschman C.S. \& Legrand M. Facing COVID-19 in the ICU: vascular dysfunction, thrombosis, and dysregulated inflammation. Intensive Care Med. 2020,46(6):1105-1108. https://doi.org/10.1007/s00134-020-06059-6.

Li B., Si H.R., Zhu Y., Yang X.L., Anderson D.E., Shi Z.L., Wang L.F. \& Zhou P. Correction for Li et al., "Discovery of Bat Coronaviruses through Surveillance and Probe Capture-Based Next-Generation Sequencing". mSphere. 2020,18,5(2):e00170-20. https://doi.org/10.1128/mSphere.00170-20.

Li G., Fan Y., Lai Y., Han T., Li Z., Zhou P., Pan P., Wang W., Hu D., Liu X., Zhang Q. \& Wu J. Coronavirus infections and immune responses. J Med Virol. 2020,92(4):424-432. https://doi.org/10.1002/jmv.25685.

Li H., Liu L., Zhang D., Xu J., Dai H., Tang N., Su X. \& Cao B. SARS-CoV-2 and viral sepsis: observations and hypotheses. Lancet. 2020,9,395(10235):15171520. https://doi.org/10.1016/S0140-6736(20)30920-X

Lovren F., Pan Y., Quan A., Teoh H., Wang G., Shukla P.C., Levitt K.S., Oudit G.Y., Al-Omran M., Stewart D.J., Slutsky A.S., Peterson M.D., Backx P.H., Penninger J.M. \& Verma S. Angiotensin converting enzyme-2 confers endothelial protection and attenuates atherosclerosis. Am J Physiol Heart Circ Physiol. 2008,295(4):H1377-84. https://doi.org/10.1152/ajpheart.00331.2008.

Lu R., Zhao X., Li J., Niu P., Yang B., Wu H., Wang W., Song H., Huang B., Zhu N., Bi Y., Ma X., Zhan F., Wang L., Hu T., Zhou H., Hu Z., Zhou W., Zhao L., Chen J., Meng Y., Wang J., Lin Y., Yuan J., Xie Z., Ma J., Liu W.J., Wang D., Xu W., Holmes E.C., Gao G.F., Wu G., Chen W., Shi W. \& Tan W. Genomic characterisation and epidemiology of 2019 novel coronavirus: implications for virus origins and receptor binding. Lancet. 2020,22,395(10224):565-574. https://doi.org/10.1016/S0140-6736(20)30251-8.

Ludke, M. \& Andre, M.E.D.A. (2013). Pesquisas em educação: uma abordagem qualitativa. São Paulo: E.P.U.

Luo H., Chen Q., Chen J., Chen K., Shen X. \& Jiang H. The nucleocapsid protein of SARS coronavirus has a high binding affinity to the human cellular heterogeneous nuclear ribonucleoprotein A1. FEBS Lett. 2005,9,579(12):2623-8. https://doi.org/10.1016/j.febslet.2005.03.080.

Malik V.S., Ravindra K., Attri S.V., Bhadada S.K. \& Singh M. Higher body mass index is an important risk factor in COVID-19 patients: a systematic review and meta-analysis. Environ Sci Pollut Res Int. 2020,24:1-9. https://doi.org/10.1007/s11356-020-10132-4.

Mantovani A., Beatrice G. \& Dalbeni A. Coronavirus disease 2019 and prevalence of chronic liver disease: A meta-analysis. Liver Int. 2020,40(6):1316-1320. https://doi.org/10.1111/liv.14465.

Marzi A., Gramberg T., Simmons G., Möller P., Rennekamp A.J., Krumbiegel M., Geier M., Eisemann J., Turza N., Saunier B., Steinkasserer A., Becker S., Bates P., Hofmann H. \& Pöhlmann S. DC-SIGN and DC-SIGNR interact with the glycoprotein of Marburg virus and the S protein of severe acute respiratory syndrome coronavirus. J Virol. 2004,78(21):12090-5. https://doi.org/10.1128/JVI.78.21.12090-12095.2004.

Mastellos D.C., Ricklin D. \& Lambris JD. Clinical promise of next-generation complement therapeutics. Nat Rev Drug Discov. 2019,18(9):707-729. https://doi.org/10.1038/s41573-019-0031-6.

Mehta P., McAuley D.F., Brown M., Sanchez E., Tattersall R.S. \& Manson J.J. (2020). HLH Across Speciality Collaboration, UK. COVID-19: consider cytokine storm syndromes and immunosuppression. Lancet. 2020,395(10229):1033-1034. https://doi.org/10.1016/S0140-6736(20)30628-0.

Merad M. \& Martin JC. Author Correction: Pathological inflammation in patients with COVID-19: a key role for monocytes and macrophages. Nat Rev Immunol 20(7):448. https://doi.org/10.1038/s41577-020-0353-y. Erratum for: Nat Rev Immunol. 2020,20(6):355-362.

Miyamoto Y., Saiwaki T., Yamashita J., Yasuda Y., Kotera I., Shibata S., Shigeta M., Hiraoka Y., Haraguchi T. \& Yoneda Y. Cellular stresses induce the nuclear accumulation of importin alpha and cause a conventional nuclear import block. J Cell Biol. 2004,7,165(5):617-23. https://doi.org/10.1083/jcb.200312008.

Moore J.D. The Ran-GTPase and cell-cycle control. Bioessays. 2001,23(1):77-85. https://doi.org/10.1002/1521-1878(200101)23:1<77::AIDBIES1010>3.0.CO,2-E.

Moreno-Eutimio M.A., López-Macías C. \& Pastelin-Palacios R. Bioinformatic analysis and identification of single-stranded RNA sequences recognized by TLR7/8 in the SARS-CoV-2, SARS-CoV, and MERS-CoV genomes. Microbes Infect. 2020,22(4-5):226-229. https://doi.org/10.1016/j.micinf.2020.04.009. 
Nakamura T., Hasegawa-Nakamura K., Sakoda K., Matsuyama T. \& Noguchi K. Involvement of angiotensin II type 1 receptors in interleukin-1 $\beta$-induced interleukin-6 production in human gingival fibroblasts. Eur J Oral Sci. 2011,119(5):345-51. https://doi.org/10.1111/j.1600-0722.2011.00850.x.

Narayanan K., Huang C., Lokugamage K., Kamitani W., Ikegami T., Tseng C.T. \& Makino S. Severe acute respiratory syndrome coronavirus nsp1 suppresses host gene expression, including that of type I interferon, in infected cells. $J$ Virol. 2008,82(9):4471-9. https://doi.org/10.1128/JVI.02472-07.

Noorimotlagh Z., Karami C., Mirzaee S.A., Kaffashian M., Mami S. \& Azizi M. Immune and bioinformatics identification of T cell and B cell epitopes in the protein structure of SARS-CoV-2: A systematic review. Int Immunopharmacol. 2020,86:106738. https://doi.org/10.1016/j.intimp.2020.106738.

Pan W., Wang Q. \& Chen Q. The cytokine network involved in the host immune response to periodontitis. Int J Oral Sci. 2019,5,11(3):30. https://doi.org/10.1038/s41368-019-0064-z.

Pandey S., Kawai T. \& Akira S. Microbial sensing by Toll-like receptors and intracellular nucleic acid sensors. Cold Spring Harb Perspect Biol. 2014,9,7(1):a016246. https://doi.org/10.1101/cshperspect.a016246.

Pedersen S.F. \& Ho Y.C. SARS-CoV-2: a storm is raging. J Clin Invest. 2020,1,130(5):2202-2205. https://doi.org/10.1172/JCI137647.

Peiris J.S., Guan Y. \& Yuen KY. Severe acute respiratory syndrome. Nat Med. 2004,10(12 Suppl):S88-97. https://doi.org/10.1038/nm1143.

Pereira, A.S, Shitsuka, D.M., Parreira, F.J. \& Shitsuka, R. (2018). Metodologia da pesquisa científica. Santa Maria.

Perlman S. \& Netland J. Coronaviruses post-SARS: update on replication and pathogenesis. Nat Rev Microbiol. 2009,7(6):439-50. https://doi.org/10.1038/nrmicro2147.

Pranata R., Huang I., Lim M.A. \& Wahjoepramono EJ. Impact of cerebrovascular and cardiovascular diseases on mortality and severity of COVID-19-systematic review, meta-analysis, and meta-regression. J Stroke Cerebrovasc Dis. 2020,29(8):104949. https://doi.org/10.1016/j.jstrokecerebrovasdis.2020.104949.

Qin C., Zhou L., Hu Z., Zhang S., Yang S., Tao Y., Xie C., Ma K., Shang K., Wang W. \& Tian DS. Dysregulation of Immune Response in Patients With Coronavirus 2019 (COVID-19) in Wuhan, China. Clin Infect Dis. 2020,71(15):762-768. https://doi.org/10.1093/cid/ciaa248.

Queiroz-Junior C.M., Santos A.C.P.M., Galvão I., Souto G.R., Mesquita R.A., Sá M.A. \& Ferreira A.J. The angiotensin converting enzyme 2/angiotensin-(17)/Mas Receptor axis as a key player in alveolar bone remodeling. Bone. 2019,128:115041. https://doi.org/10.1016/j.bone.2019.115041.

Rabi F.A., Al Zoubi M.S., Kasasbeh G.A., Salameh D.M. \& Al-Nasser AD. SARS-CoV-2 and Coronavirus Disease 2019: What We Know So Far. Pathogens. 2020,20,9(3):231. https://doi.org/10.3390/pathogens 9030231.

Raj V.S., Mou H., Smits S.L., Dekkers D.H., Müller M.A., Dijkman R., Muth D., Demmers J.A., Zaki A., Fouchier R.A., Thiel V., Drosten C., Rottier P.J., Osterhaus A.D., Bosch B.J. \& Haagmans B.L. Dipeptidyl peptidase 4 is a functional receptor for the emerging human coronavirus-EMC. Nature. 2013,14,495(7440):251-4. https://doi.org/10.1038/nature12005.

Read S.A., Obeid S., Ahlenstiel C. \& Ahlenstiel G. The Role of Zinc in Antiviral Immunity. Adv Nutr. 2019,1,10(4):696-710. https://doi.org/10.1093/advances/nmz013.

Risitano A.M., Mastellos D.C., Huber-Lang M., Yancopoulou D., Garlanda C., Ciceri F. \& Lambris J.D. Author Correction: Complement as a target in COVID19? Nat Rev Immunol. 2020,20(7):448. https://doi.org/10.1038/s41577-020-0366-6. Erratum for: Nat Rev Immunol. 2020,20(6):343-344.

Rodrigues M., Barbirato D., Luiz R.R., Scharfstein J., Salles G.F. \& Feres-Filho E.J. Effect of antihypertensive therapy with angiotensin-converting enzyme inhibitors on chronic periodontitis: a case-control study. Oral Dis. 2016,22(8):791-796. https://doi.org/10.1111/odi.12551.

Rowland R.R., Chauhan V., Fang Y., Pekosz A., Kerrigan M. \& Burton M.D. Intracellular localization of the severe acute respiratory syndrome coronavirus nucleocapsid protein: absence of nucleolar accumulation during infection and after expression as a recombinant protein in vero cells. $J$ Virol. 2005,79(17): 1150712. https://doi.org/10.1128/JVI.79.17.11507-11512.2005.

Santos C.F., Akashi A.E., Dionísio T.J., Sipert C.R., Didier D.N., Greene A.S., Oliveira S.H., Pereira H.J., Becari C., Oliveira E.B. \& Salgado M.C. Characterization of a local renin-angiotensin system in rat gingival tissue. J Periodontol. 2009,80(1):130-9. https://doi.org/10.1902/jop.2009.080264.

Santos C.F., Morandini A.C., Dionísio T.J., Faria F.A., Lima M.C., Figueiredo C.M., Colombini-Ishikiriama B.L., Sipert C.R., Maciel R.P., Akashi A.P., Souza G.P., Garlet G.P., Rodini C.O., Amaral S.L., Becari C., Salgado M.C., Oliveira E.B., Matus I., Didier D.N. \& Greene A.S. Func tional Local Renin-Angiotensin System in Human and Rat Periodontal Tissue. PLoS One. 2015,5,10(8):e0134601. https://doi.org/10.1371/journal.pone.0134601.

Sato H., Masuda M., Miura R., Yoneda M. \& Kai C. Morbillivirus nucleoprotein possesses a novel nuclear localization signal and a CRM1-independent nuclear export signal. Virology. 2006,15,352(1):121-30. https://doi.org/10.1016/j.virol.2006.04.013.

Schett G., Sticherling M. \& Neurath M.F. COVID-19: risk for cytokine targeting in chronic inflammatory diseases? Nat Rev Immunol. 2020,20(5):271-272. https://doi.org/10.1038/s41577-020-0312-7.

Shereen M.A., Khan S., Kazmi A., Bashir N. \& Siddique R. COVID-19 infection: Origin, transmission, and characteristics of human coronaviruses. J Adv Res. 2020,16,24:91-98. https://doi.org/10.1016/j.jare.2020.03.005.

Siu K.L., Chan C.P., Kok K.H., Chiu-Yat Woo P. \& Jin D.Y. Suppression of innate antiviral response by severe acute respiratory syndrome coronavirus M protein is mediated through the first transmembrane domain. Cell Mol Immunol. 2014,11(2):141-9. https://doi.org/10.1038/cmi.2013.61.

Sluimer J.C., Gasc J.M., Hamming I., van Goor H., Michaud A., van den Akker L.H., Jütten B., Cleutjens J., Bijnens A.P., Corvol P., Daemen M.J. \& Heeneman S. Angiotensin-converting enzyme 2 (ACE2) expression and activity in human carotid atherosclerotic lesions. J Pathol. 2008,215(3):273-9. https://doi.org/10.1002/path.2357. 
Small B.A., Dressel S.A., Lawrence C.W., Drake D.R. 3rd, Stoler M.H., Enelow R.I. \& Braciale T.J. CD8(+) T cell-mediated injury in vivo progresses in the absence of effector T cells. J Exp Med. 2001,194(12):1835-46. https://doi.org/10.1084/jem.194.12.1835.

Smith V., Seo D., Warty R., Payne O., Salih M., Chin K.L., Ofori-Asenso R., Krishnan S, da Silva Costa F., Vollenhoven B. \& Wallace E. Maternal and neonatal outcomes associated with COVID-19 infection: A systematic review. PLoS One. 2020,4,15(6):e0234187. https://doi.org/10.1371/journal.pone.0234187.

Su S. \& Jiang S. A suspicious role of interferon in the pathogenesis of SARS-CoV-2 by enhancing expression of ACE2. Signal Transduct Target Ther. 2020,21,5(1):71. https://doi.org/10.1038/s41392-020-0185-z.

Tay M.Z., Poh C.M., Rénia L., MacAry P.A. \& Ng L.F.P. The trinity of COVID-19: immunity, inflammation and intervention. Nat Rev Immunol. 2020,20(6):363-374. https://doi.org/10.1038/s41577-020-0311-8

Terpos E., Ntanasis-Stathopoulos I., Elalamy I., Kastritis E., Sergentanis T.N., Politou M., Psaltopoulou T., Gerotziafas G. \& Dimopoulos M.A. Hematological findings and complications of COVID-19. Am J Hematol. 2020,95(7):834-847. https://doi.org/10.1002/ajh.25829.

Tian S., Hu W., Niu L., Liu H., Xu H. \& Xiao S.Y. Pulmonary Pathology of Early-Phase 2019 Novel Coronavirus (COVID-19) Pneumonia in Two Patients With Lung Cancer. J Thorac Oncol. 2020,15(5):700-704. https://doi.org/10.1016/j.jtho.2020.02.010.

Tijms M.A., van der Meer Y. \& Snijder E.J. Nuclear localization of non-structural protein 1 and nucleocapsid protein of equine arteritis virus. J Gen Virol. 2002,83(Pt 4):795-800. https://doi.org/10.1099/0022-1317-83-4-795

Timani K.A., Liao Q., Ye L., Zeng Y., Liu J., Zheng Y., Ye L., Yang X., Lingbao K., Gao J. \& Zhu Y. Nuclear/nucleolar localization properties of C-terminal nucleocapsid protein of SARS coronavirus. Virus Res. 2005,114(1-2):23-34. https://doi.org/10.1016/j.virusres.2005.05.007.

Tseng C.T., Perrone L.A., Zhu H., Makino S. \& Peters C.J. Severe acute respiratory syndrome and the innate immune responses: modulation of effector cell function without productive infection. J Immunol. 2005,174(12):7977-85. https://doi.org/10.4049/jimmunol.174.12.7977.

Uddin M.H., Zonder J.A. \& Azmi A.S. Exportin 1 inhibition as antiviral therapy. Drug Discov Today. 2020,20:S1359-6446(20)30239-7. https://doi.org/10.1016/j.drudis.2020.06.014.

van Boheemen S., de Graaf M., Lauber C., Bestebroer T.M., Raj V.S., Zaki A.M., Osterhaus A.D., Haagmans B.L., Gorbalenya A.E., Snijder E.J. \& Fouchier R.A. Genomic characterization of a newly discovered coronavirus associated with acute respiratory distress syndrome in humans. $m$ Bio. 2012,20,3(6):e0047312. https://doi.org/10.1128/mBio.00473-12.

Wan Y., Shang J., Graham R., Baric R.S. \& Li F. Receptor Recognition by the Novel Coronavirus from Wuhan: an Analysis Based on Decade-Long Structural Studies of SARS Coronavirus. J Virol. 2020,17,94(7):e00127-20. https://doi.org/10.1128/JVI.00127-20.

Wang M., Hao H., Leeper N.J. \& Zhu L, Early Career Committee. Thrombotic Regulation From the Endothelial Cell Perspectives. Arterioscler Thromb Vasc Biol. 2018,38(6):e90-e95. https://doi.org/10.1161/ATVBAHA.118.310367.

Wang N., Shi X., Jiang L., Zhang S., Wang D., Tong P., Guo D., Fu L., Cui Y., Liu X., Arledge K.C., Chen Y.H., Zhang L. \& Wang X. Structure of MERSCoV spike receptor-binding domain complexed with human receptor DPP4. Cell Res. 2013,23(8):986-93. https://doi.org/10.1038/cr.2013.92.

Wilk A.J., Rustagi A., Zhao N.Q., Roque J., Martínez-Colón G.J., McKechnie J.L., Ivison G.T., Ranganath T., Vergara R., Hollis T., Simpson L.J., Grant P., Subramanian A., Rogers A.J. \& Blish C.A. A single-cell atlas of the peripheral immune response in patients with severe COVID-19. Nat Med. 2020,26(7): 10701076. https://doi.org/10.1038/s41591-020-0944-y.

World Health Organisation. (2020b) Clinical Management of severe acute respiratory infection when novel coronavirus (2019-nCoV) infection is suspected. Available online at https://apps.who.int/iris/ handle/10665/330893.

World Health Organization. (2020a) Laboratory testing for coronavirus disease 2019 (COVID-19) in suspected human cases: interim guidance, 2 March 2020. Available online at https://apps.who.int/iris/handle/10665/331329.

Wu A., Peng Y., Huang B., Ding X., Wang X., Niu P., Meng J., Zhu Z., Zhang Z., Wang J., Sheng J., Quan L., Xia Z., Tan W., Cheng G. \& Jiang T. Genome Composition and Divergence of the Novel Coronavirus (2019-nCoV) Originating in China. Cell Host Microbe. 2020a,11,27(3):325-328. https://doi.org/10.1016/j.chom.2020.02.001.

Wu F., Zhao S., Yu B., Chen Y.M., Wang W., Song Z.G., Hu Y., Tao Z.W., Tian J.H., Pei Y.Y., Yuan M.L., Zhang Y.L., Dai F.H., Liu Y., Wang Q.M., Zheng J.J., Xu L., Holmes E.C. \& Zhang Y.Z. Author Correction: A new coronavirus associated with human respiratory disease in China. Nature. 2020,580(7803):E7. https://doi.org/10.1038/s41586-020-2202-3. Erratum for: Nature. 2020b Mar,579(7798):265-269.

Wu K.E., Fazal F.M., Parker K.R., Zou J.\& Chang H.Y. RNA-GPS Predicts SARS-CoV-2 RNA Residency to Host Mitochondria and Nucleolus. Cell Syst. 2020,22,11(1):102-108.e3. https://doi.org/10.1016/j.cels.2020.06.008.

Wulan W.N., Heydet D., Walker E.J., Gahan M.E. \& Ghildyal R. Nucleocytoplasmic transport of nucleocapsid proteins of enveloped RNA viruses. Front Microbiol. 2015,2,6:553. https://doi.org/10.3389/fmicb.2015.00553.

Wurm T., Chen H., Hodgson T., Britton P., Brooks G. \& Hiscox J.A. Localization to the nucleolus is a common feature of coronavirus nucleoproteins, and the protein may disrupt host cell division. J Virol. 2001,75(19):9345-56. https://doi.org/10.1128/JVI.75.19.9345-9356.2001.

Xu H., Zhong L., Deng J., Peng J., Dan H., Zeng X., Li T. \& Chen Q. High expression of ACE2 receptor of 2019-nCoV on the epithelial cells of oral mucosa. Int J Oral Sci. 2020,24,12(1):8. https://doi.org/10.1038/s41368-020-0074-X.

Xu Z., Shi L., Wang Y., Zhang J., Huang L., Zhang C., Liu S., Zhao P., Liu H., Zhu L., Tai Y., Bai C., Gao T., Song J., Xia P., Dong J., Zhao J. \& Wang FS. Pathological findings of COVID-19 associated with acute respiratory distress syndrome. Lancet Respir Med. 2020,8(4):420-422. https://doi.org/10.1016/S22132600(20)30076-X. 
Yang J., Zheng Y., Gou X., Pu K., Chen Z., Guo Q., Ji R., Wang H., Wang Y. \& Zhou Y. Prevalence of comorbidities and its effects in patients infected with SARS-CoV-2: a systematic review and meta-analysis. Int J Infect Dis. 2020,94:91-95. https://doi.org/10.1016/j.ijid.2020.03.017.

Yang Z.Y., Huang Y., Ganesh L., Leung K., Kong W.P., Schwartz O., Subbarao K. \& Nabel G.J. pH-dependent entry of severe acute respiratory syndrome coronavirus is mediated by the spike glycoprotein and enhanced by dendritic cell transfer through DC-SIGN. J Virol. 2004,78(11):5642-50. https://doi.org/10.1128/JVI.78.11.5642-5650.2004.

Yilla M., Harcourt B.H., Hickman C.J., McGrew M., Tamin A., Goldsmith C.S., Bellini W.J. \& Anderson L.J. SARS-coronavirus replication in human peripheral monocytes/macrophages. Virus Res. 2005,107(1):93-101. https://doi.org/10.1016/j.virusres.2004.09.004.

Yoo D., Wootton S.K., Li G., Song C. \& Rowland R.R. Colocalization and interaction of the porcine arterivirus nucleocapsid protein with the small nucleolar RNA-associated protein fibrillarin. J Virol. 2003,77(22):12173-83. https://doi.org/10.1128/jvi.77.22.12173-12183.2003.

Yoshikawa T., Hill T., Li K., Peters C.J. \& Tseng C.T. Severe acute respiratory syndrome (SARS) coronavirus-induced lung epithelial cytokines exacerbate SARS pathogenesis by modulating intrinsic functions of monocyte-derived macrophages and dendritic cells. $J$ Virol. 2009,83(7):3039-48. https://doi.org/10.1128/JVI.01792-08

Young R.E., Thompson R.D., Larbi K.Y., La M., Roberts C.E., Shapiro S.D., Perretti M. \& Nourshargh S. Neutrophil elastase (NE)-deficient mice demonstrate a nonredundant role for NE in neutrophil migration, generation of proinflammatory mediators, and phagocytosis in response to zymosan particles in vivo. $J$ Immunol. 2004,172(7):4493-502. https://doi.org/10.4049/jimmunol.172.7.4493.

Yuki K., Fujiogi M. \& Koutsogiannaki S. COVID-19 pathophysiology: A review. Clin Immunol. 2020,215:108427. https://doi.org/10.1016/j.clim.2020.108427. Zaigham M. \& Andersson O. Maternal and perinatal outcomes with COVID-19: A systematic review of 108 pregnancies. Acta Obstet Gynecol Scand. 2020,99(7):823-829. https://doi.org/10.1111/aogs.13867.

Zeng H., Pappas C., Belser J.A., Houser K.V., Zhong W., Wadford D.A., Stevens T., Balczon R., Katz J.M. \& Tumpey TM. Human pulmonary microvascular endothelial cells support productive replication of highly pathogenic avian influenza viruses: possible involvement in the pathogenesis of human $\mathrm{H} 5 \mathrm{~N} 1$ virus infection. J Virol. 2012,86(2):667-78. https://doi.org/10.1128/JVI.06348-11.

Zhang B., Zhou X., Qiu Y., Song Y., Feng F., Feng J., Song Q., Jia Q. \& Wang J. Clinical characteristics of 82 cases of death from COVID-19. PLoS One. 2020,9,15(7):e0235458. https://doi.org/10.1371/journal.pone.0235458.

Zhang H., Penninger J.M., Li Y., Zhong N. \& Slutsky A.S. Angiotensin-converting enzyme 2 (ACE2) as a SARS-CoV-2 receptor: molecular mechanisms and potential therapeutic target. Intensive Care Med. 2020,46(4):586-590. https://doi.org/10.1007/s00134-020-05985-9.

Zhang Z.L., Hou Y.L., Li D.T. \& Li FZ. Laboratory findings of COVID-19: a systematic review and meta-analysis. Scand J Clin Lab Invest. 2020,23:1-7. https://doi.org/10.1080/00365513.2020.1768587.

Zheng M., Gao Y., Wang G., Song G., Liu S., Sun D., Xu Y. \& Tian Z. Functional exhaustion of antiviral lymphocytes in COVID-19 patients. Cell Mol Immunol. 2020,17(5):533-535. https://doi.org/10.1038/s41423-020-0402-2.

Zhou F., Yu T., Du R., Fan G., Liu Y., Liu Z., Xiang J., Wang Y., Song B., Gu X., Guan L., Wei Y., Li H., Wu X., Xu J., Tu S., Zhang Y., Chen H. \& Cao B. Clinical course and risk factors for mortality of adult inpatients with COVID-19 in Wuhan, China: a retrospective cohort study. Lancet. 2020,395(10229): 10541062. https://doi.org/10.1016/S0140-6736(20)30566-3.

Zhou P., Yang X.L., Wang X.G., Hu B., Zhang L., Zhang W., Si H.R., Zhu Y., Li B., Huang C.L., Chen H.D., Chen J., Luo Y., Guo H., Jiang R.D., Liu M.Q., Chen Y., Shen X.R., Wang X., Zheng X.S., Zhao K., Chen Q.J., Deng F., Liu L.L., Yan B., Zhan F.X., Wang Y.Y., Xiao G.F. \& Shi ZL. A pneumonia outbreak associated with a new coronavirus of probable bat origin. Nature. 2020,579(7798):270-273. https://doi.org/10.1038/s41586-020-2012-7.

Zhou P., Yang X.L., Wang X.G., Hu B., Zhang L., Zhang W., Si H.R., Zhu Y., Li B., Huang C.L., Chen H.D., Chen J., Luo Y., Guo H., Jiang R.D., Liu M.Q., Chen Y., Shen X.R., Wang X., Zheng X.S., Zhao K., Chen Q.J., Deng F., Liu L.L., Yan B., Zhan F.X., Wang Y.Y., Xiao G.F. \& Shi Z.L. A pneumonia outbreak associated with a new coronavirus of probable bat origin. Nature. 2020,579(7798):270-273. https://doi.org/10.1038/s41586-020-2012-7.

Zhu N., Zhang D., Wang W., Li X., Yang B., Song J., Zhao X., Huang B., Shi W., Lu R., Niu P., Zhan F., Ma X., Wang D., Xu W., Wu G., Gao G.F., Tan W., China Novel Coronavirus Investigating and Research Team. A Novel Coronavirus from Patients with Pneumonia in China, 2019. 2020,20,382(8):727-733. https://doi.org/10.1056/NEJMoa2001017.

Ziegler C.G.K., Allon S.J., Nyquist S.K., Mbano I.M., Miao V.N., Tzouanas C.N., Cao Y., Yousif A.S., Bals J., Hauser B.M., Feldman J., Muus C., Wadsworth M.H. 2nd, Kazer S.W., Hughes T.K., Doran B., Gatter G.J., Vukovic M., Taliaferro F., Mead B.E., Guo Z., Wang J.P., Gras D., Plaisant M., Ansari M., Angelidis I., Adler H., Sucre J.M.S., Taylor C.J., Lin B., Waghray A., Mitsialis V., Dwyer D.F., Buchheit K.M., Boyce J.A., Barrett N.A., Laidlaw T.M., Carroll S.L., Colonna L., Tkachev V., Peterson C.W., Yu A., Zheng H.B., Gideon H.P., Winchell C.G., Lin P.L., Bingle C.D., Snapper S.B., Kropski J.A., Theis F.J., Schiller H.B., Zaragosi L.E., Barbry P., Leslie A., Kiem H.P., Flynn J.L., Fortune S.M., Berger B., Finberg R.W., Kean L.S., Garber M., Schmidt A.G., Lingwood D., Shalek A.K. \& Ordovas-Montanes J, HCA Lung Biological Network. Electronic address: lung-network@ humancellatlas.org, HCA Lung Biological Network. SARS-CoV-2 Receptor ACE2 Is an Interferon-Stimulated Gene in Human Airway Epithelial Cells and Is Detected in Specific Cell Subsets across Tissues. Cell. 2020,28,181(5):1016-1035.e19. https://doi.org/10.1016/j.cell.2020.04.035.

Zou X., Chen K., Zou J., Han P., Hao J. \& Han Z. Single-cell RNA-seq data analysis on the receptor ACE2 expression reveals the potential risk of different human organs vulnerable to 2019-nCoV infection. Front Med. 2020,14(2):185-192. https://doi.org/10.1007/s11684-020-0754-0. 